University of Nebraska - Lincoln

DigitalCommons@University of Nebraska - Lincoln

\title{
Comparison of DAYCENT-Simulated and Measured Nitrous Oxide Emissions from a Corn Field
}

\author{
Marek K. Jarecki \\ AgCert, Mjarecki@agcert.com \\ Timothy B. Parkin \\ National Soil Tilth Laboratory \\ Alvarus S. K. Chan \\ AgCert \\ Jerry L. Hatfield \\ National Soil Tilth Laboratory, jerry.hatfield@ars.usda.gov \\ Raymond Jones \\ AgCert
}

Follow this and additional works at: https://digitalcommons.unl.edu/usdaarsfacpub

Jarecki, Marek K.; Parkin, Timothy B.; Chan, Alvarus S. K.; Hatfield, Jerry L.; and Jones, Raymond,

"Comparison of DAYCENT-Simulated and Measured Nitrous Oxide Emissions from a Corn Field" (2008).

Publications from USDA-ARS / UNL Faculty. 1362.

https://digitalcommons.unl.edu/usdaarsfacpub/1362

This Article is brought to you for free and open access by the U.S. Department of Agriculture: Agricultural Research Service, Lincoln, Nebraska at DigitalCommons@University of Nebraska - Lincoln. It has been accepted for inclusion in Publications from USDA-ARS / UNL Faculty by an authorized administrator of DigitalCommons@University of Nebraska - Lincoln. 


\section{Comparison of DAYCENT-Simulated and Measured Nitrous Oxide Emissions from a Corn Field}

\author{
Marek K. Jarecki* AgCert, a subsidiary of The AES Corporation \\ Timothy B. Parkin National Soil Tilth Laboratory \\ Alvarus S. K. Chan AgCert, a subsidiary of The AES Corporation \\ Jerry L. Hatfield National Soil Tilth Laboratory \\ Raymond Jones AgCert, a subsidiary of The AES Corporation
}

Accurate assessment of $\mathrm{N}_{2} \mathrm{O}$ emission from soil require continuous year-round and spatially extensive monitoring or the use of simulation that accurately and precisely predict $\mathrm{N}_{2} \mathrm{O}$ fluxes based on climatic, soil, and agricultural system input data. DAYCENT is an ecosystem model that simulates, among other processes, $\mathrm{N}_{2} \mathrm{O}$ emissions from soils. The purpose of the study was to compare $\mathrm{N}_{2} \mathrm{O}$ fluxes predicted by the DAYCENT model to measured $\mathrm{N}_{2} \mathrm{O}$ fluxes from an experimental corn field in central Iowa. Soil water content temperature and inorganic $\mathrm{N}$, simulated by DAYCENT were compared to measured values of these variables. Field $\mathrm{N}_{2} \mathrm{O}$ emissions were measured using four replicated automated chambers at 6-h intervals, from day of year (DOY) 42 through DOY 254 of 2006 . We observed that DAYCENT generally accurately predicted soil temperature, with the exception of winter when predicted temperatures tended to be lower than measured values. Volumetric water contents predicted by DAYCENT were generally lower than measured values during most of the experimental period. Daily $\mathrm{N}_{2} \mathrm{O}$ emissions simulated by DAYCENT were significantly correlated to field measured fluxes; however, time series analyses indicate that the simulated fluxes were out of phase with the measured fluxes. Cumulative $\mathrm{N}_{2} \mathrm{O}$ emission calculated from the simulations ( $3.29 \mathrm{~kg} \mathrm{~N}_{2} \mathrm{O}-\mathrm{N} \mathrm{ha}^{-1}$ ) was in range of the measured cumulative $\mathrm{N}_{2} \mathrm{O}$ emission $\left(4.26 \pm 1.09 \mathrm{~kg} \mathrm{~N}_{2} \mathrm{O}-\mathrm{N} \mathrm{ha}^{-1}\right)$.

Copyright $\odot 2008$ by the American Society of Agronomy, Crop Science Society of America, and Soil Science Society of America. All rights reserved. No part of this periodical may be reproduced or transmitted in any form or by any means, electronic or mechanical, including photocopying, recording, or any information storage and retrieval system, without permission in writing from the publisher.

Published in J. Environ. Qual. 37:1685-1690 (2008). doi:10.2134/jeq2007.0614

Received 26 Nov. 2007.

*Corresponding author (Mjarecki@agcert.com).

( ) ASA, CSSA, SSSA

677 S. Segoe Rd., Madison, WI 53711 USA
$I^{\mathrm{T}}$ is widely recognized that agricultural activities are a major contributor to atmospheric emissions of $\mathrm{N}_{2} \mathrm{O}$ (Kroeze et al., 1999); however, accurate estimation of soil $\mathrm{N}_{2} \mathrm{O}$ emissions remains problematic due to high temporal and spatial variability. Coefficients of variation associated with spatial variability often exceed $100 \%$ (Matthias et al., 1980; Ambus and Christensen, 1994; Yates et al., 2006). Temporal variations associated with $\mathrm{N}_{2} \mathrm{O}$ emissions can vary by three orders of magnitude over a time period of days. Transient peaks in $\mathrm{N}_{2} \mathrm{O}$ emissions have been observed in response to rainfall, fertilization events, and freeze-thaw cycles (Bremner et al., 1981; Goodroad and Keeney, 1984; Cates and Keeney, 1987; Clayton et al., 1997; Jacinthe and Dick, 1997; Wagner-Riddle and Thurtell, 1998; Baggs et al., 2003; Sehy et al., 2003; Gregorich et al., 2005; Parkin and Kaspar, 2006; Parkin, 2008).

Measurement techniques to characterize the spatial and temporal variations in $\mathrm{N}_{2} \mathrm{O}$ emissions are limited. Micrometerological techniques have been applied to provide spatially integrated flux estimates and high temporal frequencies (Wagner-Riddle and Thurtell, 1998; Edwards et al., 2003). As a less expensive alternative to micrometerological instrumentation, soil chamber techniques have been widely applied. Soil chambers are amenable to replicated studies where treatment differences can be assessed. However, in the past, the temporal intensities of the short-term flux measurements performed with soil chambers have ranged from semiweekly to monthly (Jacinthe and Dick, 1997; Wang et al., 2006). Recently it has been reported that the precision associated with estimates of cumulative $\mathrm{N}_{2} \mathrm{O}$ emissions decreases as the time between sampling increases (Parkin, 2008).

Mathematical models that predict $\mathrm{N}_{2} \mathrm{O}$ emissions offer an alternative to direct measurements. Models ranging from a simple emissions factor approach to more complex biophysical models have been developed (IPCC, 2001, Li et al., 2006; Parton et al., 1998). DAYCENT is as an ecosystem model that that estimates several variables including soil temperature and soil moisture, and $\mathrm{N}_{2} \mathrm{O}$ emissions (Parton et al., 1998; Del Grosso et al., 2001). Recent studies show that DAYCENT can be used to estimate long-term dynamics of water, carbon, and nitrogen (Li et al., 2006). An assessment of DAYCENT's ability to simulate cumulative annual $\mathrm{N}_{2} \mathrm{O}$ emissions has also been performed

M.K. Jarecki, AgCert USA, Inc., 1990 W. New Haven Ave., Suite 205, Melbourne, FL 32904. T.B. Parkin and J.L. Hatfield, National Soil Tilth Lab., 2110 University Blvd., Ames, IA 50011. A.S.K. Chan, AgCert USA, Inc., 1990 W. New Haven Ave., Suite 205, Melbourne, FL 32904. R. Jones, AgCert Canada Co., 309 1st Street W., High River, AB T1V 1M5, Canada. 
Table 1. Properties of soil in the 0 - to $15-\mathrm{cm}$ layer.

\begin{tabular}{ll} 
Property & Value \\
\hline $\mathrm{pH}$ & 6.7 \\
Bulk density Mg m & 1.26 \\
Sand $\left(\mathrm{g} \mathrm{kg}^{-1}\right.$ soil) & 420 \\
Clay $\left(\mathrm{g} \mathrm{kg}^{-1}\right.$ soil) & 200 \\
Organic carbon $(\mathrm{g} \mathrm{C} \mathrm{kg}$ & 31.0 \\
Water field capacity $\left(\mathrm{cm}^{3}\right.$ water $\mathrm{cm}^{-3}$ soil) & 0.355 \\
Permanent wilting point $\left(\mathrm{cm}^{3}\right.$ water cm $\mathrm{cm}^{-3}$ soil) & 0.125 \\
Saturated hydraulic conductivity $\left(\mathrm{cm} \mathrm{h}^{-1}\right)$ & 0.851 \\
\hline
\end{tabular}

(Del Grosso et al., 2005, 2008). Del Grosso et al. (2005) compared annual estimates of $\mathrm{N}_{2} \mathrm{O}$ emissions based on measured fluxes with estimates based on DAYCENT simulations for a variety of cropping systems in five regions of the United States. Annual estimates from the DAYCENT model underestimated the annual estimates based on measured $\mathrm{N}_{2} \mathrm{O}$ emissions by approximately 23\%. Conversely, the DAYCENT model was recently tested at the field scale at a site in northeastern Colorado. It was observed that growing season estimates predicted by DAYCENT overestimated flux estimates based on measured emissions for $\mathrm{N}$ treatments about two times and for no $\mathrm{N}$ treatments about four times (Del Grosso et al., 2008). These investigators concluded that modifications to the microbial $\mathrm{N}$-cycling subroutines are required to improve the simulation accuracy.

A key feature of the DAYCENT model is the fact that daily estimates of $\mathrm{N}_{2} \mathrm{O}$ emissions are provided. However, a detailed comparison of predicted and measured $\mathrm{N}_{2} \mathrm{O}$ emissions on a daily time step has not yet been performed. To date, most of the data used to validate DAYCENT has come from manual chamber measurements that were made, at most, several times per week. A comparison of predicted fluxes with fluxes measured at a higher sampling frequency would provide valuable information regarding the fidelity of the underlying mechanistic structure of the $\mathrm{N}_{2} \mathrm{O}$ emissions component of the DAYCENT model. Thus, the purpose of this study was to compare temporal variations in measured daily $\mathrm{N}_{2} \mathrm{O}$ fluxes from an experimental corn field with the predicted fluxes obtained from the DAYCENT model. Also, since temperature and water content are major drivers of $\mathrm{N}_{2} \mathrm{O}$ production in the DAYCENT model we compared DAYCENTsimulated soil temperature and soil water content to measured values of these properties.

\section{Methods}

The field component of this study was conducted in a chisel plow corn/soybean field on an Iowa State University research farm located in Boone Co., Iowa $\left(42.04^{\circ} \mathrm{N}, 93.71^{\circ} \mathrm{W}\right)$. The soil with loam texture is characterized as a Canisteo clay loam soil (fine-loamy, mixed, superactive, calcareous, mesic Typic Endoaquolls). The soil properties are presented in Table 1. On 14 Nov. 2005 anhydrous ammonia was applied at a rate of $168 \mathrm{~kg} \mathrm{~N} \mathrm{ha}^{-1}$ with a knife injector in bands separated by a distance of $76 \mathrm{~cm}$. On 5 May 2006 corn was planted at 74,074 seeds ha' $\mathrm{ha}^{-1}$

Nitrous oxide fluxes were measured using automated chambers similar in design to those described by Parkin and Kaspar (2003). The chambers $(0.60 \mathrm{~m} \times 0.60 \mathrm{~m} \times 0.30 \mathrm{~m}$ tall $)$ were installed to a depth of $20 \mathrm{~cm}$ in the soil in February 2006. Two chambers were located directly over fertilizer bands and two chambers were located between fertilizer bands. Nitrous oxide fluxes were measured every $6 \mathrm{~h}$ from 25 Feb. 2006 (DOY 42) through 11 Oct. 2006 (DOY 254). Fluxes were measured by sliding the cover over the chamber top to close the chamber and allow $\mathrm{N}_{2} \mathrm{O}$ to accumulate in the chamber headspace over a $2 \mathrm{~h}$ period. Headspace $\mathrm{N}_{2} \mathrm{O}$ concentrations were measured in each chamber at $1 / 2-h$ intervals by pumping approximately $0.1 \mathrm{~L}$ of headspace gas through as sample valve attached to a gas chromatograph equipped with an electron capture detector (SRI Instruments, model 8610, Torrance, CA). Additional details on gas sampling and analyses are provided by Parkin (2008). Nitrous oxide fluxes were calculated from the headspace $\mathrm{N}_{2} \mathrm{O}$ concentration vs. time data using linear regression by the method of Hutchinson and Mosier (1981). Daily $\mathrm{N}_{2} \mathrm{O}$ fluxes were computed for each chamber by averaging the four flux measurements performed each day. Daily average $\mathrm{N}_{2} \mathrm{O}$ fluxes for the field were computed using the daily average fluxes of each chamber and associated $95 \%$ confidence intervals for the daily average $\mathrm{N}_{2} \mathrm{O}$ fluxes were also computed.

Each chamber was instrumented with thermocouples to measure air and soil temperature within each chamber. Soil temperature was measured at depths of $1,5,10$, and $20 \mathrm{~cm}$ below the soil surface. Air temperature in each chamber was measured with a thermocouple shielded from direct sunlight, and suspended approx. $8 \mathrm{~cm}$ above the soil surface. Soil moisture probes (DeltaT Theta Probes, Dynamax, Houston, TX) were installed in the surface soil $(0$ to $6 \mathrm{~cm})$ of the chambers. Temperature and soil water content measurements were made at hourly intervals. Daily averages of temperature and soil water content were computed from the hourly values for the DAYCENT comparison.

Surface soil $(0-15 \mathrm{~cm})$ was sampled six times during the period between April and July, 2006 by collecting soil cores (3.35 $\mathrm{cm}$ diam.) within and between fertilizer bands. Twelve soil cores were collected at different locations near the gas flux chambers at each sampling time. In the laboratory samples were weighed and sieved $(2 \mathrm{~mm})$. Subsamples were collected for gravimetric water content determination by oven drying at $105^{\circ} \mathrm{C}$, and the remaining soil was air dried. Bulk density was computed from the soil sample weights (corrected for water content) and the known core volume. Volumetric water contents were calculated from the gravimetric water contents and bulk density values. Nitrate (+ nitrite) and ammonium were determined by colorimetric analyses of $2 \mathrm{~mol} \mathrm{~L}^{-1} \mathrm{KCl}$ soil extracts (4:1 $\mathrm{KCl}$ to soil) on a Lachat (Mequon, WI) autoanalyzer following the procedure described by Keeney and Nelson (1982).

The DAYCENT simulation was performed using local climatic factors (daily air minimum and maximum temperature and daily precipitation), soil parameters (bulk density, texture, organic carbon content, $\mathrm{pH}$, saturated hydraulic conductivity), and crop and soil management factors (type and amount of $\mathrm{N}$ fertility, tillage, crop). It should be noted that since the chambers were closed approximately $8 \mathrm{~h}$ every day (i.e., 4 2-h periods per day) during the flux measurements, not all of the precipitation measured with the tipping bucket gauge reached the soil inside the chambers. To more accurately simulate the $\mathrm{N}_{2} \mathrm{O}$ emissions 
measured in the chambers, the daily precipitation data set used by DAYCENT did not include precipitation that occurred during times when the soil chambers were closed. Output from the DAYCENT model included soil water content $(0-2 \mathrm{~cm}$, 2-5 cm), soil temperature (surface, $5 \mathrm{~cm}, 10 \mathrm{~cm}$ ) and daily $\mathrm{N}_{2} \mathrm{O}$ emissions. Cumulative $\mathrm{N}_{2} \mathrm{O}$ emissions over the study period were performed by linear interpolation and numerical integration of both the measured and predicted daily fluxes.

Statistical differences in cumulative $\mathrm{N}_{2} \mathrm{O}$ emissions were assessed by comparing the DAYCENT-predicted values with the $95 \%$ confidence intervals of the measured cumulative emissions. A comparison of the temporal patterns of the predicted and measured daily $\mathrm{N}_{2} \mathrm{O}$ emissions was performed using cross correlation analyses (Statistics for Windows 2.0; Analytical Software, 1998).

\section{Results}

\section{Soil Temperature and Soil Moisture}

Comparison of the measured soil temperatures with the DAYCENT-predicted temperatures yielded close relationships (Fig. 1). The correlation coefficients for the measured vs. predicted surface, $5 \mathrm{~cm}$, and $10 \mathrm{~cm}$ temperatures were $0.96,0.96$, and 0.98 , respectively. Despite the high correlation coefficient at the 10-cm layer, predicted temperatures were lower than measured (Fig. 1c). Predicted and measured average soil temperatures (10 $\mathrm{cm}$ ) over the entire period were 13.5 and $15.3^{\circ} \mathrm{C}$, respectively.

Predicted soil water content and measured soil water content, along with 95\% confidence intervals are presented in Fig. 2. The correlation between predicted and measured soil water content was significant, but low $(r=0.263)$. Generally, predicted soil water content $(0-5 \mathrm{~cm})$ was significantly lower than water measured volumetric soil water $(0-6 \mathrm{~cm})$. The primary differences between the patterns of measured and predicted soil water contents appear to occur during drying periods. Following rainfall events, predicted soil water contents generally increased to levels approaching the measured values, but the simulations exhibit greater decreases in soil water content than were observed after these peak events. As a check on the values obtained from the soil moisture probes, soil water contents were determined by soil sampling $(0-15 \mathrm{~cm})$ and gravimetric analysis on six occasions. Despite the fact that the soil depth interval of these gravimetrically determined values was different from the soil moisture probes, they were within the $95 \%$ confidence limits of the probe measurements, and significantly higher than predicted values (Fig. 2).

\section{Nitrous Oxide Emission}

Predicted and measured daily $\mathrm{N}_{2} \mathrm{O}$ emissions over the sampling period along with temperature and rainfall are shown in Fig. 3. Throughout the sampling period several peak $\mathrm{N}_{2} \mathrm{O}$ emissions occurred in response to rainfall events. These peak events resulted in as much as a 10- to 20-fold increases in $\mathrm{N}_{2} \mathrm{O}$ emissions over a period of 4 to $5 \mathrm{~d}$ (e.g., DOY 196-200). Daily $\mathrm{N}_{2} \mathrm{O}$ fluxes predicted by the DAYCENT model generally followed the pattern of measured emissions; however, some discrepancies are observed. For example between DOY 97 and DOY 127 the

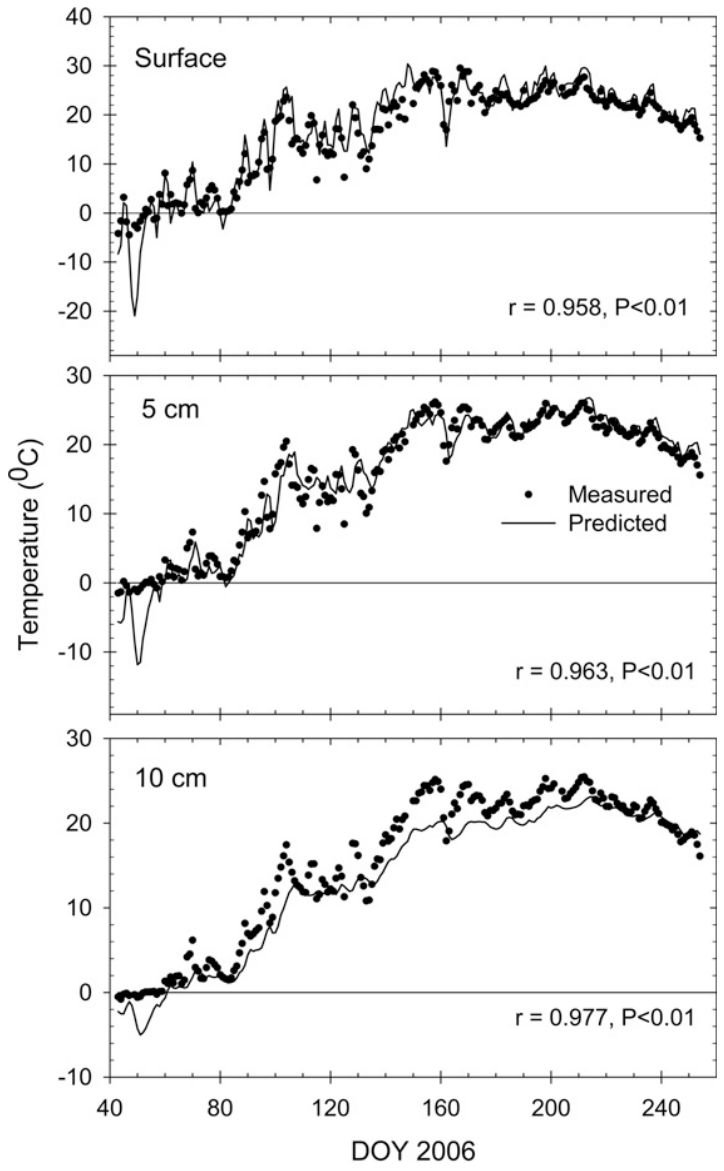

Fig. 1. Measured and DAYCENT-simulated soil temperature at surface, 5 and $10 \mathrm{~cm}$.

predicted fluxes were greater than the upper $97.5 \%$ confidence limit of the measured emissions. Predicted fluxes were also greater than measured fluxes on several days during the period of DOY 130 to 147 . From DOY 170 through DOY 254, predicted fluxes exhibited increases in response to rainfall events; however, the magnitudes of the simulated peaks were several folds less than the measured values, and on several of these occasions these differences were significant (Fig. 3).

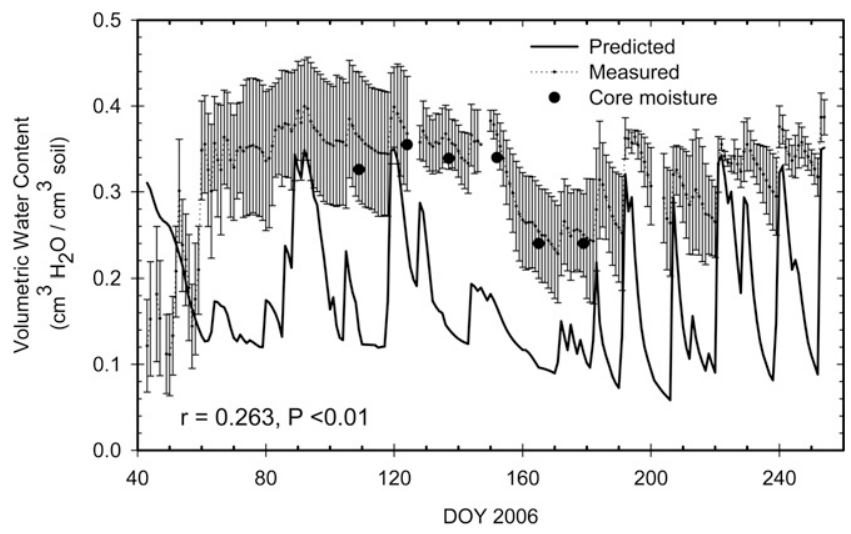

Fig. 2. Measured $(0-6 \mathrm{~cm})$ and predicted $(0-5 \mathrm{~cm})$ volumetric water content. Error bars associated with means of measured soil water contents are standard deviations. Points are volumetric soil water content $(0-15 \mathrm{~cm}) \mathrm{cm}$ determined by gravimetric analyses of soil. 

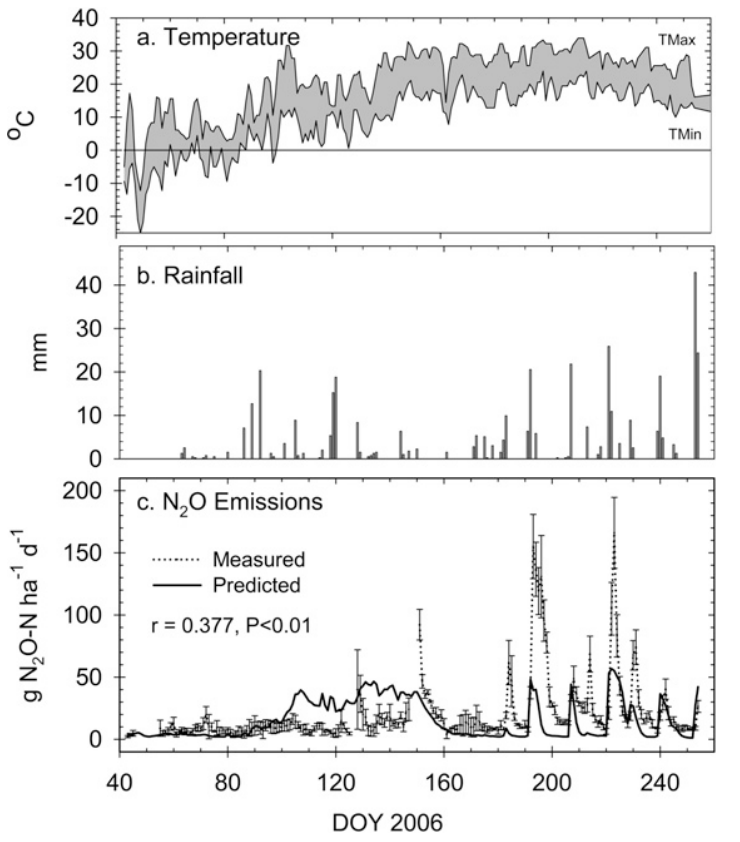

Fig. 3. Measured maximum and minimum daily air temperature (panel a), precipitation (panel b), and measured and predicted daily $\mathrm{N}_{2} \mathrm{O}$ emissions (panel c). Solid line is simulation, dotted line is mean of four chamber measurements. Error bars are $95 \%$ confidence intervals associated with measured means.

Correlation analysis between measured and predicted daily $\mathrm{N}_{2} \mathrm{O}$ fluxes yielded a correlation coefficient of 0.37 (Fig. 4). This correlation was significant; however, the tendency of the model to overpredict $\mathrm{N}_{2} \mathrm{O}$ fluxes at the low range and underpredict fluxes at the high range is evident. When integrated over the entire experimental period, DAYCENT simulations provide an estimate of cumulative $\mathrm{N}_{2} \mathrm{O}$ loss of $3.29 \mathrm{~kg} \mathrm{~N}_{2} \mathrm{O}-\mathrm{N} \mathrm{ha}^{-1}$. This value is lower than the average cumulative $\mathrm{N}_{2} \mathrm{O}$ loss measured by the chambers $\left(4.26 \mathrm{~kg} \mathrm{~N}_{2} \mathrm{O}-\mathrm{N} \mathrm{ha}^{-1}\right)$, but is in range of the $95 \%$ confidence interval of measured cumulative $\mathrm{N}_{2} \mathrm{O}$ loss (5.37 to $3.18 \mathrm{~kg} \mathrm{~N}_{2} \mathrm{O}-\mathrm{N} \mathrm{ha}^{-1}$ ).

Cross correlation analysis provides an assessment of similarities of variables as a function of separation in time (or space). When applied to the measured and predicted daily $\mathrm{N}_{2} \mathrm{O}$ fluxes, cross correlation analysis provided an indica-

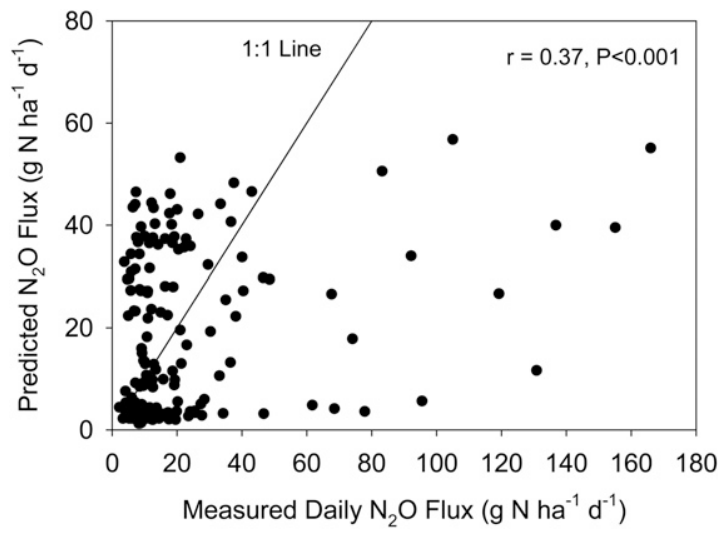

Fig. 4. Correlation between measured and predicted daily $\mathrm{N}_{2} \mathrm{O}$ emission values.

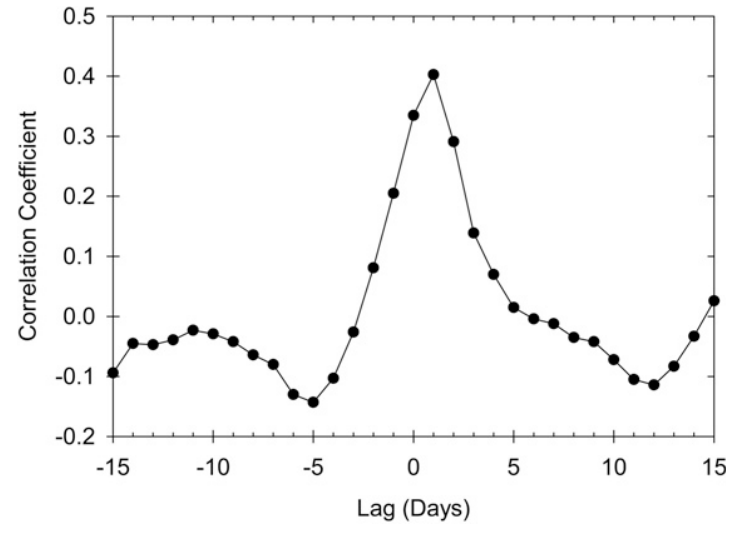

Fig. 5. Cross correlation analysis of predicted and measured $\mathrm{N}_{2} \mathrm{O}$ emissions

tion of the similarities in the temporal patterns (Fig. 5). It is observed that the greatest correlation coefficient $(r=0.403)$ occurs at a lag of $1 \mathrm{~d}$. This indicates that the best correlation occurs between predicted fluxes and fluxes measured $1 \mathrm{~d}$ later.

On six occasions throughout the study period soil nitrate and ammonium were measured in the 0 - to $15-\mathrm{cm}$ layer, both within and between the anhydrous ammonia fertilizer bands applied in 2005 (Fig. 6). Soil nitrate was underestimated by the DAYCENT model on all of the sampling dates. On average the $\mathrm{NO}_{3}^{-}$concentrations of the between-band samples were over two times higher than the predicted values, and the in-band $\mathrm{NO}_{3}{ }^{-}$concentrations were nearly eight times higher than the simulations. The predicted $\mathrm{NH}_{4}^{+}$values on DOY 109 and DOY 124 were greater than the measured betweenband $\mathrm{NH}_{4}^{+}$values, but less than the in-band $\mathrm{NH}_{4}^{+}$concentrations. During the rest of sampling dates (DOY 137, 153, 165, and 179) the model continued to simulate $\mathrm{NH}_{4}^{+}$concentrations on average in excess of 60 to $70 \mathrm{mg} \mathrm{NH}_{4}{ }^{+} \mathrm{N} \mathrm{kg}^{-1}$ soil.

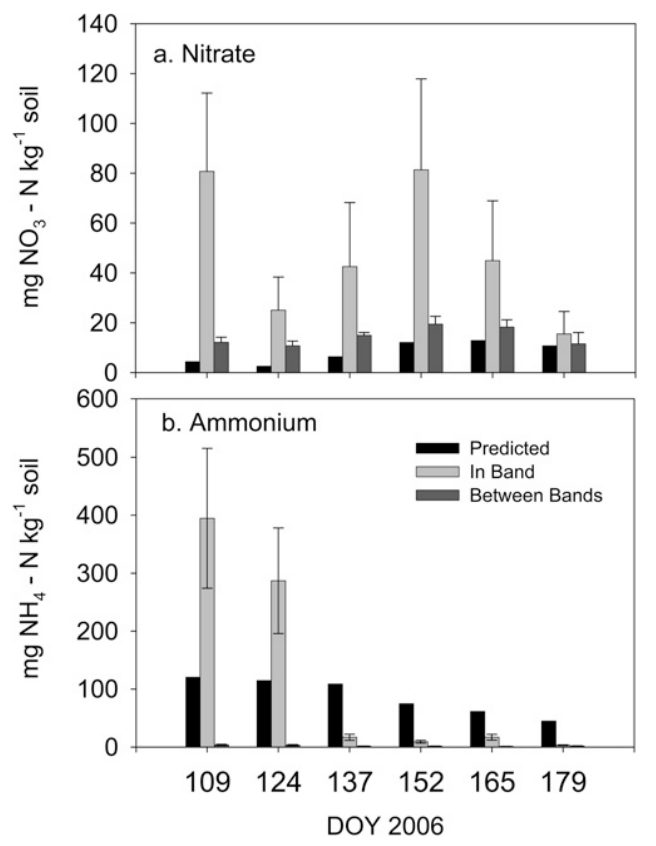

Fig. 6. Predicted and measured soil $\mathrm{NO}_{3}{ }^{-}$and $\mathrm{NH}_{4}^{+}$concentrations $(0-15 \mathrm{~cm})$ on six sampling dates. Error bars associated with means are standard deviations. 


\section{Discussion}

Estimation of trace gas emissions, and particularly $\mathrm{N}_{2} \mathrm{O}$, from agricultural systems has become more important as the search for improved management systems to reduce GHG emissions intensifies. Clearly, mathematical models play a role in this process of estimation and evaluation. The application of models can allow prediction of responses to climatic variability or changes in the soil and crop management and enable theoretical assessments of how changing management practices may influence net $\mathrm{N}_{2} \mathrm{O}$ emissions. However, these potential functions may only be realized if it is assured that accurate predictions are obtained.

The DAYCENT model has been evaluated in several studies. Parton et al. (2001) found that DAYCENT provided favorable predictions of soil temperature $\left(r^{2}=0.79\right)$, and soil water filled pore space $\left(r^{2}=0.64\right)$, but considered the simulations of soil water content during the non-growing season to be inadequate $\left(r^{2}=0.27\right)$. Our assessment of the DAYCENT model was similar to these results. We observed strong correlations with soil temperature $(r \geq 0.95)$, but weak correlation with soil water content $(r=0.26)$. In their assessments of $\mathrm{N}_{2} \mathrm{O}$ emissions at five sites in Colorado, Parton et al. (2001) found that regressions of measured vs. predicted daily $\mathrm{N}_{2} \mathrm{O}$ emissions yielded regression coefficients $\left(r^{2}\right)$ between 0.02 and 0.19 . Despite the low correlation between measured and predicted daily fluxes, these investigators reported a close match between measured cumulative annual estimates and estimates obtained with the model. A similar finding was observed when DAYCENT predictions were compared with flux data from no-till and conventional till systems in Nebraska (Del Grosso et al., 2002), where it was concluded that, although the regression of the measured vs. predicted regression was low $\left(r^{2}=0.04\right)$, DAYCENT accurately predicted average annual $\mathrm{N}_{2} \mathrm{O}$ emissions. Similar to these past studies, we observed a low correlation between measured and predicted daily $\mathrm{N}_{2} \mathrm{O}$ fluxes $(r=0.37)$. Unlike past studies, however, we report that predicted cumulative $\mathrm{N}_{2} \mathrm{O}$ emission was significantly less than measured cumulative $\mathrm{N}_{2} \mathrm{O}$ loss. The difference between our measured and predicted cumulative flux estimates appears to be largely due to DAYCENT's underestimation of peak flux events that were observed following rainfall events. When we delete the 14 largest daily fluxes (from both the predicted and measured data sets) the difference between cumulative predicted and measured $\mathrm{N}_{2} \mathrm{O}$ fluxes was insignificant (measured $=2.81 \mathrm{~kg} \mathrm{~N} \mathrm{ha}^{-1}$; predicted $=2.63 \mathrm{~kg} \mathrm{~N} \mathrm{ha}^{-1}$ ). There may be several reasons why the DAYCENT model underpredicted daily $\mathrm{N}_{2} \mathrm{O}$ emissions at our site. First, we observed that the DAYCENT-predicted soil water dynamics did not accurately reflect our measurements. Predicted increases in soil water content following rainfall events approached values of measured soil water content; however, predicted water contents decreased more rapidly after rainfall events. Differences between predicted and measured soil water content do not completely explain the differences in predicted and measured fluxes. On several dates following rainfall events (i.e., DOY 183, 192, 222) predicted soil water contents were not significantly different from measured soil water content; however, the predicted peak $\mathrm{N}_{2} \mathrm{O}$ fluxes that occurred in response to increased soil water content occurred $1 \mathrm{~d}$ earlier than measured $\mathrm{N}_{2} \mathrm{O}$ peaks, and were three to six times less than the measured peak $\mathrm{N}_{2} \mathrm{O}$ emissions. Differences between predicted and actual soil inorganic N could be a factor. From DOY 109 through DOY 179 DAYCENT underestimated soil $\mathrm{NO}_{3}{ }^{-}$concentrations and overestimated soil $\mathrm{NH}_{4}^{+}$concentrations from DOY 137 through 179. A similar observation was reported by Del Grosso et al. (2008) who observed that DAYCENT underestimated soil $\mathrm{NO}_{3}^{-}$levels. These authors concluded that improvements in DAYCENT's $\mathrm{N}_{2} \mathrm{O}$ prediction could be improved by modifying the nitrification and denitrification subroutines. Another potential issue related to modeling $\mathrm{N}$ transformations is fertilizer placement. The DAYCENT model allows input of the form of fertilizer $\mathrm{N}$ (as proportions of $\mathrm{NH}_{4}^{+}$ and $\mathrm{NO}_{3}^{-}$); however, there is no provision for designating spatial placement of fertilizer. At our site where anhydrous ammonia was injected as bands into the soil, there were distinct spatial variations in $\mathrm{NO}_{3}{ }^{-}$and $\mathrm{NH}_{4}^{+}$concentrations. DAYCENT models $\mathrm{N}$ transformations as a function of depth, but cannot take into account spatial variations in the surface soil.

\section{Summary and Conclusions}

In general, past assessments of the DAYCENT model have reported good correlations of predicted and measured cumulative $\mathrm{N}_{2} \mathrm{O}$ loss. In our study predicted and measured cumulative $\mathrm{N}_{2} \mathrm{O}$ emissions were of similar magnitude. It may be argued that if the model generally yields accurate predictions of cumulative or average $\mathrm{N}_{2} \mathrm{O}$ emissions, that this is sufficient. However, if the model is, in essence, getting the "right" answer for the "wrong" reasons, then its utility as a tool to predict the influence of management changes on $\mathrm{N}_{2} \mathrm{O}$ emissions may be limited. With such uncertainty, there will be lack of confidence in the result. Continued efforts are needed to apply and evaluate DAYCENT models across a range of soils, climates, and management systems. Improvements in the $\mathrm{N}$ cycling components of DAYCENT (Del Grosso et al., 2008) as well as a mechanism for on-site calibration would likely be useful in future applications of this model.

\section{Acknowledgments}

We thank Dr. Arvin Mosier for comments and Cindy Keough for technical assistance. This work is supported, in part, by the USDA-ARS GRACEnet project.

\section{References}

Ambus, P., and S. Christensen. 1994. Measurement of $\mathrm{N}_{2} \mathrm{O}$ emission from a fertilized grassland-An analysis of spatial variability. J. Geophys. Res. Atmos. 99:16549-16555.

Analytical Software. 1998. Statistix for Windows 2.0. Analytical Software, Tallahassee, FL.

Baggs, E.M., M. Stevenson, M. Pihlatie, A. Regar, H. Cook, and G. Cadisch. 2003. Nitrous oxide emissions following application of residues and fertiliser under zero and conventional tillage. Plant Soil 254:361-370.

Bremner, J.M., G.A. Breitenbeck, and A.M. Blackmer. 1981. Effect of anhydrous ammonia fertilization on emission of nitrous oxide from soils. J. Environ. Qual. 10:77-80.

Cates, R.L., and D.R. Keeney. 1987. Nitrous oxide production throughout the year from fertilized and manured maize fields. J. Environ. Qual. 16:443-447.

Clayton, H., I.P. McTaggart, J. Parker, L. Swan, and K.A. Smith. 1997. 
Nitrous oxide emissions from fertilised grassland: A 2-year study of the effects of $\mathrm{N}$ fertiliser form and environmental conditions. Biol. Fertil. Soils 25:252-260.

Del Grosso, S., A.D. Halvorson, and W.J. Parton. 2008. Testing the DAYCENT model using crop yield and $\mathrm{N}_{2} \mathrm{O}$ data from irrigated rotations in Colorado. J. Environ. Qual. 37:1383-1389.

Del Grosso, S.J., A.R. Mosier, W.J. Parton, and D.S. Ojima. 2005. DAYCENT model analysis of past and contemporary soil $\mathrm{N}_{2} \mathrm{O}$ and net greenhouse gas flux for major crops in the USA. Soil Tillage Res. 83:9-24.

Del Grosso, S., D. Ojima, W. Parton, A. Mosier, G. Peterson, and D. Schimel. 2002. Simulated effects of dryland cropping intensification on soil organic matter and greenhouse gas exchanges using the DAYCENT ecosystem model. Environ. Pollut. 116:S75-S83.

Del Grosso, S.J., W.J. Parton, A.R. Mosier, M.D. Hartman, J. Brenner, D.S. Ojima, and D.S. Schimel. 2001. Simulated interaction of carbon dynamics and nitrogen trace gas fluxes using the DAYCENT model. p. 303-332. In M. Schaffer et al. (ed.) Modeling carbon and nitrogen dynamics for soil management. CRC Press, Boca Raton, FL.

Edwards, G.C., G.W. Thurtell, and G.E. Kidd. 2003. A diode laser based gas monitor suitable for measurement of trace gas exchange using micrometeorogical techniques. Agric. For. Meteorol. 115:71-89.

Goodroad, L.L., and D.R. Keeney. 1984. Nitrous oxide emission from forest, marsh, and prairie ecosystems. J. Environ. Qual. 13:448-452.

Gregorich, E.G., P. Rochette, A.J. VandenBygaart, and D.A. Angers. 2005. Greenhouse gas contributions of agricultural soils and potential mitigation practices in Eastern Canada. Soil Tillage Res. 83:53-72.

Hutchinson, G.L., and A.R. Mosier. 1981. Improved soil cover method for field measurement of nitrous oxide fluxes. Soil Sci. Soc. Am. J. 45:311-316.

IPCC. 2001. Climate change 2001: The scientific basis. Intergovermental Panel on Climate Change. p. 881. In J.J. Houghton et al. (ed.) Cambridge Univ. Press, Cambridge, UK.

Jacinthe, P.-A., and W.A. Dick. 1997. Soil management and nitrous oxide emissions from cultivated fields in southern Ohio. Soil Tillage Res. 41:221-235.

Keeney, D.R., and D.W. Nelson. 1982. Nitrogen-Inorganic forms. p. 643-698. In A.L. Page et al. (ed.) Methods of soil analysis. Part 2. 2nd ed. Agron. Monogr. 9. ASA and SSSA, Madison, WI.
Kroeze, C., A.R. Mosier, and A.F. Bouwman. 1999. Closing the global $\mathrm{N}_{2} \mathrm{O}$ budget: A retrospective analysis 1500-1994. Glob. Biogeochem. Cycles $13: 1-8$.

Li, X., T. Meixner, J.O. Sickman, A.E. Miller, J.P. Schmiel, and J.M. Melack. 2006. Decadal-scale dynamics of water, carbon and nitrogen in a California chaparral ecosystem: DAYCENT modeling results. Biogeochemistry 77:217-245.

Matthias, A.D., A.M. Blackmer, and J.M. Bremner. 1980. A simple chamber technique for field measurement of emissions of nitrous oxide from soils. J. Environ. Qual. 9:251-256.

Parkin, T.B. 2008. Effect of sampling frequency on estimates of cumulative $\mathrm{N}_{2} \mathrm{O}$ emissions. J. Environ. Qual. 37:1390-1395.

Parkin, T.B., and T.C. Kaspar. 2003. Temperature controls and diurnal carbon dioxide flux: Implications for estimating soil carbon loss. Soil Sci. Soc. Am. J. 67:1763-1772.

Parkin, T.B., and T.C. Kaspar. 2006. Nitrous oxide emissions from cornsoybean systems in the Midwest. J. Environ. Qual. 35:1496-1506.

Parton, W.J., E.A. Holland, S.J. Del Grosso, M.D. Hartman, R.E. Martin, A.R. Mosier, D.S. Ojima, and D.S. Schimel. 2001. Generalized model for $\mathrm{NOx}$ and $\mathrm{N}_{2} \mathrm{O}$ emissions from soils. J. Geophys. Res. 106:17403-17419.

Parton, W.J., M.D. Hartman, D.S. Ojima, and D.S. Schmiel. 1998. DAYCENT: Its land surface submodel-description and testing. Glob. Planet Change 19:35-48.

Sehy, U., R. Ruser, and J.C. Munch. 2003. Nitrous oxide fluxes from maize fields: Relationship to yield, site-specific fertilization, and soil conditions. Agric. Ecosyst. Environ. 99:97-111.

Wagner-Riddle, C., and G.W. Thurtell. 1998. Nitrous oxide emission from agricultural fields during winter and spring thaw as affected by management practices. Nutr. Cycling Agroecosyst. 52:151-163.

Wang, H., W. Wang, C. Yina, Y. Wang, and J. Lua. 2006. Littoral zones as the "hotspots" of nitrous oxide $\left(\mathrm{N}_{2} \mathrm{O}\right)$ emission in a hyper-eutrophic lake in China. Atmos. Environ. 40:5522-5527.

Yates, T.T., B.C. Si, R.E. Farrell, and D.J. Pennock. 2006. Probability distribution and spatial dependence of nitrous oxide emission: Temporal change in hummocky terrain. Soil Sci. Soc. Am. J. 70:353-362. 